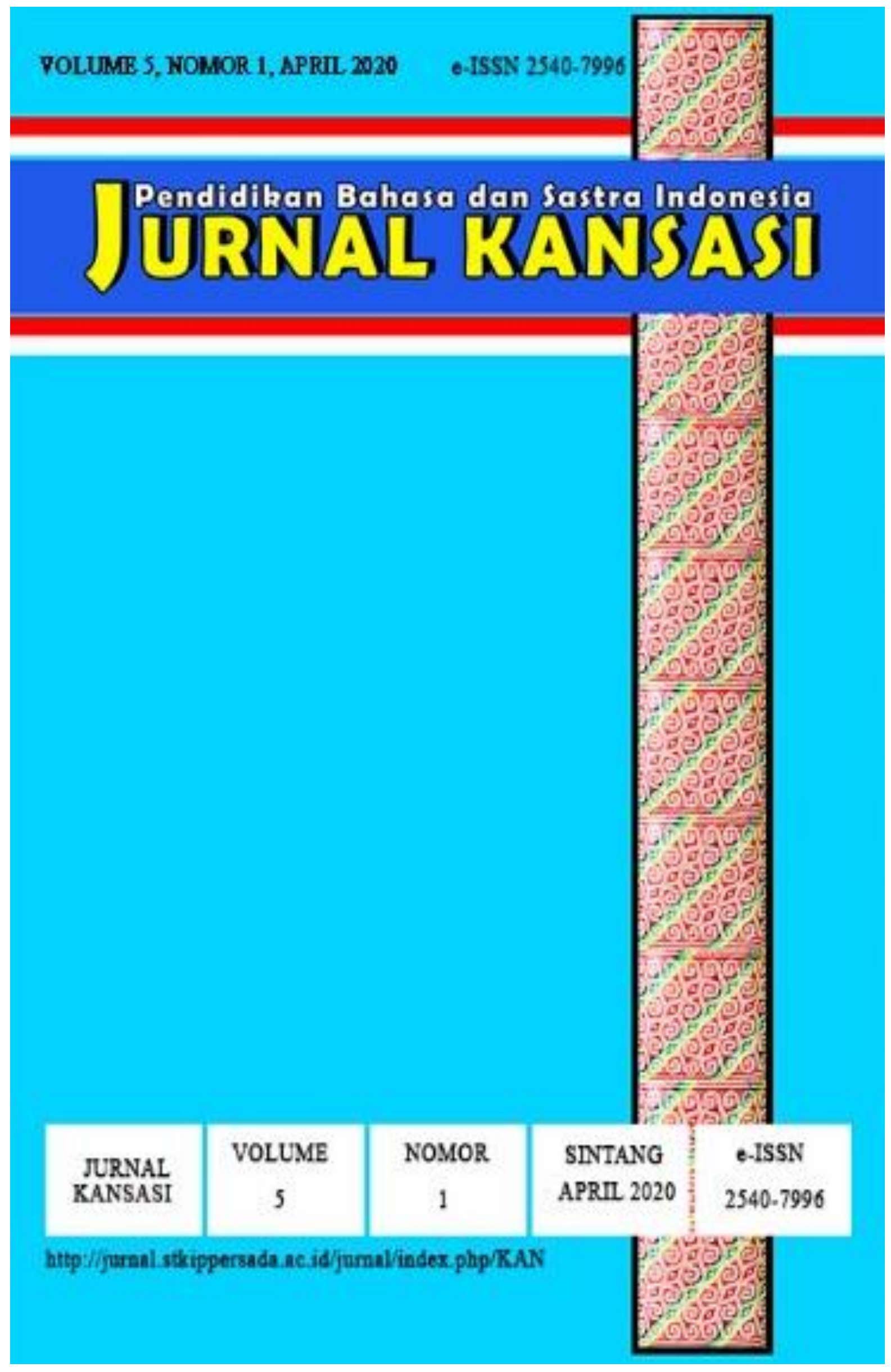




\section{JURNAL KANSASI \\ Volume 5, Nomor 1, April 2020}

Jurnal online pendidikan bahasa dan sastra Indonesia terbit dua kali setahun yaitu pada bulan April dan Oktober. Berisi tulisan yang diangkat dari hasil telaah dan penelitian di bidang pendidikan, bahasa, dan sastra Indonesia.

\section{Editor In Chief}

Debora Korining Tyas

\section{Deputy Chief Editor}

Sri Astuti

\section{Editor}

Tedi Suryadi

Ursula Dwi Oktaviani

Yudita Susanti

Muhammad Thamimi

Muchammad Djarot

\section{Reviewer}

Yusuf Olang

Herpanus

Bani Sudardi

Yoseph Yapi Taum

Agus Wartiningsih

\section{Administratative Staffs \\ Valentinus Ola Beding \\ Evi Fitrianingrum}

Alamat Redkasi: Program Studi Pendidikan Bahasa dan Sastra Indonesia STKIP Persada Khatulistiwa Sintang, Jl. Pertamina Sengkuang, Kotak Pos 126, Hp/WA. 082150544710.

Website e-journal KANSASI: http://jurnal.stkippersada.ac.id/jurnal/index.php/KAN

Jurnal ilmiah online KASASI diterbitkan oleh Program Studi Pendidikan Bahasa dan Sastra Indonesia STKIP Persada Khatulistiwa Sintang. Terbit sejak April 2016.

Penyunting menerima tulisan ilmiah yang belum pernah diterbitkan dimedia lain, baik cetak maupun elektronik. Naskah diketik untuk ukuran HVS A4 dengan spasi satu koma lima, maksimal 20 halaman. Tulisan yang masuk direview dan selanjutnya untuk diterbitkan. 


\section{JURNAL KANSASI \\ Volume 5, Nomor 1, April 2020}

\section{DAFTAR ISI}

Halaman

Hubungan Kemandirian Belajar Terhadap Hasil Belajar Siswa pada Mata Pelajaran Bahasa Indonesia Kelas VIII $1-8$

SMP N 02 Tempunak

\section{Herpanus, Evi Fitria Ningrum, Ahensius Bantut}

STKIP Persada Khatulistiwa Sintang

Analisis Kesulitan Membaca Permulaan pada Sub Tema Tugasku

Sebagai Umat Beragama pada Siswa Kelas II SD Negeri 06

Setapang Laut Ketungau Hilir

Ursula Dwi Oktaviani, Gabriel Serani, Etikustini

STKIP Persada Khatulistiwa Sintang

Analisis Struktural Kumpulan Cerita Rakyat

Dayak Jangkang Tanjung

Valentinus Ola Beding, Tedi Suaryadi, Frideta Heni

STKIP Persada Khatulistiwa Sintang

Peningkatan Keterampilan Menulis Karangan Deskripsi

Menggunakan Media Miniatur (Maket)

Debora Korining Tyas, Sudarto, Ahmad Ridho Inoviar

STKIP Persada Khatulistiwa Sintang

Hubungan Kebiasaan Menulis dengan Kemampuan Menulis Cerpen pada Siswa Kelas XI Sekolah Menengah Atas

Nusantara Indah Sintang

Yusuf Olang, Evi Fitrianingrum, Markulanus Alex

$55-63$

STKIP Persada Khatulistiwa Sintang

Peningkatan Hasil Belajar Siswa Menggunakan

Metode Talking Stick pada Pembelajaran Tematik

Tedi Suryadi, Meranti Sintauli Tampubolon

$64-70$

STKIP Persada Khatulistiwa Sintang

Peningkatan Penguasaan Kosakata Bahasa Indonesia

Menggunakan Media Gambar pada Siswa Kelas 1

Sekolah Dasar Negeri 43 Tapang Aceh Tahun Ajaran 2019/2020

$71-80$

Gabriel Serani, Ilinawati, Lidia Heni

STKIP Persada Khatulistiwa Sintang 
Hubungan Hasil Belajar Siswa Dengan Kemampuan

Menerapkan Nilai-Nilai Pancasila

Agnesia Hartini, Lukas Robinson

$81-91$

STKIP Persada Khatulistiwa Sintang

Proses Dan Makna Simbol Ritual Munjong Dayak Tobag

Yudita Susanti, Yusuf Olang, Marselina Risca

$92-98$

STKIP Persada Khatulistiwa Sintang

Penerapan Pendekatan Eksploratory Discovery untuk Meningkatkan

Motivasi dan Hasil Belajar Kognitif

Sirilus Sirhi, Hendrikus Julung, Valentina Suci Susanti

$99-112$

STKIP Persada Khatulistiwa Sintang

Analisis Makna Bahasa Promosi Katalog Oriflame

Edisi Bulan Januari-Maret Tahun 2019

$113-126$

Ursula Dwi Oktaviani, Debora Korining Tyas, Ira Winarti

STKIP Persada Khatulistiwa Sintang

Peran Guru Pkn dalam Membina Civic Skill Siswa

Sekolah Menengah Pertama Negeri 7

Agnesia Hartini, Simon Petrus

$127-137$

STKIP Persada Khatulistiwa Sintang 
Vol. 5, No. 1, April 2020

e-ISSN: 2540-7996

http://jurnal.stkippersada.ac.id/jurnal/index.php/KAN/index

\title{
PENINGKATAN HASIL BELAJAR SISWA MENGGUNAKAN METODE TALKING STICK PADA PEMBELAJARAN TEMATIK
}

\author{
Tedi Suryadi' ${ }^{1}$ Meranti Sintauli Tampubolon², \\ ${ }^{1}$ STKIP Persada Khatulistiwa, ${ }^{2}$ STKIP Persada Khatulistiwa, \\ e-mail: tedisuryadi.198724@gmail.com ${ }^{1}$, ullyshintatampubolon@gmail.com² \\ Diajukan, 7 Februari 2020, Diterima, 5 Maret 2020, Dterbitkan, 1 April 2020
}

\begin{abstract}
ABSTRAK
Abstrak: Penelitian ini bertujuan untuk mendeskripsikan penerapan metode Talking Stick, aktivitas siswa ketika diterapkan metode Talking Stick, dan hasil belajar siswa setelah diterapkan metode Talking Stick. Penelitian ini menggunakan rancangan Penelitian Tindakan Kelas (PTK) dengan dua siklus dan masing-masing siklus terdapat dua kali pertemuan. Instrumen pengumpulan data menggunakan lembar observasi, lembar wawancara, soal tes dan dokumentasi. Metode penelitian yang digunakan yaitu metode deskriptif dengan pendekatan kualitatif. Hasil penelitian menunjukkan bahwa penerapan metode Talking Stick dapat meningkatkan hasil belajar siswa dalam pembelajaran tematik Sekolah Dasar Negeri 01 Sepauk. Hasil belajar siswa kelas V mengalami peningkatan setelah diterapkan metode Talking Stick. Hasil belajar kogntitif siswa siklus I sebesar 72\% dan Siklus II sebesar 94\%. Hasil belajar Afektif aspek jujur 21 siswa sudah membudayakan dan 13 siswa mulai berkembang, aspek disiplin 19 siswa sudah membudayakan dan 15 siswa mulai berkembang, aspek bertanggung jawab 11 siswa sudah membudayakan dan 23 siswa mulai berkembang, aspek percaya diri 18 siswa sudah membudaykan dan 16 siswa mulai berkembang. Hasil belajar Psikomotorik 26 siswa mendapat predikat nilai A dan 7 siswa predikat nilai B, serta 1 siswa predikat nilai C. Berdasarkan hasil penelitian, metode pembelajaran Talking Stick dapat meningkatkan hasil belajar kognitif, afektif, dan psikomotorik siswa.
\end{abstract}

Kata Kunci: Hasil Belajar, metode Talking Stick, Pembelajaran Tematik 
Vol. 5, No. 1, April 2020

e-ISSN: 2540-7996

http://jurnal.stkippersada.ac.id/jurnal/index.php/KAN/index

\begin{abstract}
Abstract: This study aims to describe the application of the Talking Stick method, student activities when the Talking Stick method is applied, and student learning outcomes after the Talking Stick method is applied. This study used a Classroom Action Research (CAR) design with two cycles and each cycle contained two meetings. Data collection instruments used observation sheets, interview sheets, test questions and documentation. The research method used is descriptive method with a qualitative approach. The results showed that the application of the Talking Stick method could improve student learning outcomes in the thematic learning of Sepauk State Elementary School. Class V student learning outcomes have improved after the Talking Stick method was applied. Cognitive learning outcomes of students in the first cycle by $72 \%$ and Cycle II by 94\%. Affective learning outcomes honest aspects 21 students have been civilizing and 13 students have begun to develop, disciplinary aspects 19 students have been civilizing and 15 students have begun to develop, responsible aspects 11 students have already been civilizing and 23 students have begun to develop, confident aspects 18 students have civilized and 16 students began to develop. Psychomotor learning outcomes 26 students got the A grade and 7 students were $B$ grade, and 1 student had a $C$ grade. Based on the results of the study, the Talking Stick learning method can improve students' cognitive, affective, and psychomotor learning outcomes.
\end{abstract}

Keywords: Learning Outcomes, Talking Stick method, Thematic Learning 
Vol. 5, No. 1, April 2020

e-ISSN: 2540-7996

http://jurnal.stkippersada.ac.id/jurnal/index.php/KAN/index

PENDAHULUAN

Pembelajaran tematik merupakan suatu sistem pembelajaran yang memungkinkan siswa, baik secara individual maupun kelompok, aktif menggali dan menemukan konsep secara prinsip-prinsip keilmuan. Pembelajaran tematik menekanan pada keterkaitan dan keterpaduan antara KD, materi pembelajaran, kegiatan pembelajaran, indikator pencapaian kompetensi, penilaian, dan sumber belajar dalam satu keutuhan pengalaman belajar. Awalnya penerapan pembelajaran menggunakan tema di sekolah dasar dianggap sulit dan membingungkan karena media yang dipakai jarang digunakan untuk semua mata pembelajaran di dalam tema. Sehingga setiap mata pelajaran yang ada di dalam tema terkadang menggunakan media yang berganti-ganti dan berkaitan dengan penyampaian berbagai mata pelajaran pada suatu tema. Hal ini membuat guru berkewajiban untuk meningkatkan kualitas pada pembelajaran siswa di kelas. Keberhasilan siswa dalam belajar tidak dapat dipisahkan dari kualitas pengajaran yang diberikan guru dan kemampuan yang dimiliki siswa itu sendiri. Karena dua unsur ini berbanding lurus dengan hasil belajar. Artinya, semakin tinggi kualitas pengajaran dan kemampuan yang dimiliki siswa, maka semakin tinggi pula hasil balajar yang diperoleh.

Menurut Sudjana (2016: 22). "Hasil belajar adalah kemampuan - kemampuan yang dimiliki siswa setelah ia menerima pengalaman belajar". Hasil belajar merupakan objek penilaian mengenai penguasaan siswa terhadap tujuan - tujuan instruksional yang dibagi menjadi beberapa kategori, antara lain keterampilan dan kebiasaan, pengetahuan dan pengertian, sikap dan cita - cita. Oleh sebab itu, dalam penilaian hasil belajar, tujuan instruksional yang berisi rumusan kemampuan dan tingkah laku yang diinginkan dikuasai siswa menjadi unsur penting sebagai dasar dan acuan penilaian.

Kurikulum 2013 mengharuskan guru untuk mampu mendesain pembelajaran dengan baik, membuat suasana pembelajaran lebih menyenangkan dan menggunakan metode pembelajaran yang dapat menarik perhatian siswa dalam setiap pembelajaran. Peneliti menerapkan metode pembelajaran yang memungkinkan siswa lebih aktif dan kreatif serta dapat meningkatkan hasil belajar siswa dengan menggunakan metode Talking Stick pada kelas V di Sekolah Dasar Negeri 01 Sepauk. Hal ini dilakukan sebagai upaya pemecahan masalah yang dihadapi oleh siswa maupun guru.

Talking Stick merupakan salah satu metode pembelajaran dari model pembelajaran kooperatif. Pembelajaran kooperatif merupakan strategi pembelajaran melalui kelompok kecil, siswa saling bekerja sama dalam memaksimalkan kondisi belajar untuk mencapai tujuan belajar. Metode Talking Stick merupakan metode pembelajaran kelompok dengan bantuan tongkat (Huda, 2014: 224). Siapa yang memegang tongkat wajib menjawab pertanyaan dari guru setelah peserta didik mempelajari materi pokoknya. Kemudian dengan bantuan Stick (tongkat) yang bergulir peserta didik dituntut untuk merefleksikan atau mengulang kembali materi yang sudah dipelajari dengan cara menjawab pertanyaan dari guru. Siapa yang memegang tongkat, dialah yang wajib menjawab pertanyaan (Talking) atau menerapkan apa yang guru perintahkan. Tongkat yang digunakan sebagai media dalam penelitian ini berbeda dengan tongkat pada umumnya yaitu terdapat variasi pada tongkat tersebut. 
Vol. 5, No. 1, April 2020

e-ISSN: 2540-7996

http://jurnal.stkippersada.ac.id/jurnal/index.php/KAN/index

Akan ada dua tongkat yang digunakan, didalam satu tongkat akan dimasukkan kertas berisi pertanyaan yang sudah digulung dan pada satu tongkatnya lagi akan digunakan sebagai perintah agar siswa melakukan apa yang guru katakan. Kedua tongkat ini akan digunakan sesuai dengan materi pada setiap pembelajaran. Pembelajaran dengan metode Talking Stick ini dapat mendorong peserta didik untuk terampil mengemukakan pendapat, terlatih dalam menyimak materi dalam waktu singkat, bekerjasama dalam kelompok dan meghargai apa yang guru katakana

\section{METODE PENELITIAN}

Metode penelitian yang digunakan dalam penelitian ini adalah metode deskriptif dengan pendekatan kualitatif. Bentuk penelitian ini merupakan Penelitian Tindakan Kelas (PTK). Penelitian ini dilaksanakan pada semester ganjil di Sekolah Dasar Negeri 01 Sepauk kelas V tahun pelajaran 2019/2020. Data yang dikumpulkan dalam penelitian ini adalah data primer dan data sekunder. Data primer adalah data yang di peroleh secara langsung data yang berdasarkan hasil dari wawancara dengan guru dan dengan melakukan observasi dengan siswa kelas V Sekolah Dasar Negeri 01 Sepauk. Data sekunder adalah data yang diperoleh secara tidak langsung dan proses penghimpunan data melalui penelusuran dokumen-dokumen sekolah yang berkaitan dengan masalah penelitian yaitu nilai siswa pada kelas V Sekolah Dasar Negeri 01 Sepauk.

Teknik pengumpulan data dalam penelitian ini dilakukan dengan cara melakukan teknik observasi, teknik pengukuran, teknik komunikasi langsung, dan teknik dokumentasi. Alat pengumpulan data yang digunakan yaitu lembar Observasi, Soal Tes, lembar Wawancara, dan Dokumentasi. Uji keabsahan data dalam penelitian ini menggunakan credibility (validitas interval) dengan menggunakan bahan referensi dan membercheck. Bahan referensi dijadikan sebagai pendukung untuk membuktikan data yang telah ditemukan oleh peneliti. Adapun bahan referensi yang digunakan dalam penelitian ini yaitu berupa rekaman suara, foto, ataupun video.

Analisis data merupakan cara yang digunakan dalam pengolahan data yang berhubungan erat dengan perumusan masalah yang telah diajukan sehingga dapat digunakan untuk menarik kesimpulan. Langkah-langkah atau tahapan yang akan digunakan peneliti untuk menganalisis data yaitu Data Collection (Pengumpulan Data), Data Reduction (Reduksi Data), Data Display (Penyajian Data), dan Kesimpulan. Data yang akan dianalisis dalam penelitian ini adalah analisis hasil tes dan analisis hasil observasi.

\section{PEMBAHASAN}

Lokasi penelitian dilakukan di Sekolah Dasar Negeri 01 Sepauk, berstatus negeri berlokasi di Desa Tanjung Ria, Kecamatan Sepauk, Kabupaten Sintang. Penelitian ini dilaksanakan pada semester ganjil tahun pelajaran 2019/2020 dikelas V SD Negeri 01 Sepauk, dengan menerapkan metode pembelajaran Talking Stick untuk meningkatkan hasil belajar siswa pada tema 4 (Sehat itu Penting) subtema 1(Peredaran Darahku Sehat). Penelitian ini dilaksanakan pada tanggal 26 November 2019 
Vol. 5, No. 1, April 2020

e-ISSN: 2540-7996

http://jurnal.stkippersada.ac.id/jurnal/index.php/KAN/index

sampai selesai. Penelitian ini dilaksanakan dengan II siklus empat kali pertemuan dengan satu kali pertemuan (6x35 menit).

Penerapan metode pembelajaran Talking Stick dapat dilihat dalam pelaksanaan observasi guru dan siswa. Berdasarkan hasil observasi guru dan siswa pada siklus I dan II, aktivitas guru dan siswa mengalami peningkatan. Hasil pengamatan tersebut menjadi gambaran tentang seberapa baik aktivitas pembelajaran dari aspek guru. Melalui observasi ini, diketahui kemampuan guru dalam mengelola pembelajaran dan menerapkan metode pembelajaran Talking Stick. Dari pemaparan deskripsi hasil observasi guru siklus I dan II, maka peneliti merekap penerapan metode pembelajaran Talking Stick.

Hasil observasi guru dari siklus I sampai siklus II mengalami peningkatan sebanyak 20\% dengan presentase rata - rata $87 \%$. Hal ini menunjukkan observasi aktivitas guru dalam pelaksanaan pembelajaran menggunakan metode pembelajaran Talking Stick sudah baik dalam penerapannya, baik dalam hal kesiapan mengajar hingga pada saat proses pembelajaran berlangsung sehingga membuat siswa menjadi terfokus untuk mengikuti pembelajaran. Kemudian, pada tahap observasi siswa untuk mendukung hasil observasi guru juga terjadi peningkatan yang sama yaitu 18\% dari 78\% menjadi 96\%.

Berdasarkan penjelasan sebelumnya mengenai peningkatan hasil belajar siklus I dan siklus II, maka telah diketahui peningkatan yang signifikan dari siklus I dan Siklus II. Berdasarkan hasil penelitian yang telah dilaksanakan, maka dapat dilihat peningkatan yang signifikan dari siklus I dan siklus II. Setelah dilakukan penelitian, soal tes pada siklus I diberikan kepada 34 orang siswa. Dari tes siklus I diperoleh sebanyak 26 siswa yang tuntas dan 8 siswa yang tidak tuntas. Nilai tertinggi siklus I adalah 100 dan terendah 60 . Hasil belajar siswa pada siklus I memperolah nilai rata-rata dari seluruh jumlah siswa 75 dengan persentase ketuntasan klasikal yang dicapai $72 \%$. Hasil tersebut memberikan kesimpulan bahwa belum memenuhi syarat ketuntasan belajar klasikal. Setelah siklus I selesai dilaksanakan dan diperoleh ketuntasan klasikal 62\%, masuk dalam kategori tidak tuntas. Maka, penelitian dilanjutkan ke siklus II.

Hasil belajar siswa pada siklus II memperoleh nilai rata-rata seluruh siswa adalah 92 dengan persentase ketuntasan klasikal 94\%. Hasil tersebut memberikan kesimpulan bahwa sudah memenuhi syarat ketuntasan belajar klasikal. Ketentuan ketuntasan belajar klasikal dicapai sekurang-kurangnya $80 \%$ dari jumlah siswa yang memperoleh nilai 65 sesuai dengan KKM yang telah ditetapkan. Dapat dilihat adanya peningkatan hasil belajar kognitif siswa dari siklus I dengan jumlah siswa tuntas 26 orang (72\%) menjadi 32 orang (94\%) pada siklus II. Dari perbandingan ketuntasan siklus I dan siklus II tersebut dapat dilihat bahwa terjadi peningkatan hasil belajar. Terjadinya peningkatan hasil belajar baik dari rata-rata maupun ketuntasan secara klasikal ini dapat disebabkan karena besarnya aktivitas siswa yang menandakan bahwa siswa mengalami dengan baik pola metode pembelajaran Talking Stick yang diterapkan oleh guru di kelas. Tingginya aktivitas siswa berdampak pada besarnya perubahan pemahaman siswa terhadap materi yang dipelajari. 
Vol. 5, No. 1, April 2020

e-ISSN: 2540-7996

http://jurnal.stkippersada.ac.id/jurnal/index.php/KAN/index

Hasil belajar ranah afektif siswa dengan menggunakan metode pembelajaran Talking Stick mengalami peningkatan dari siklus I sampai siklus II. Sebanyak 21 siswa sudah membudayakan sikap jujur dan 13 siswa mulai berkembang. Pada aspek disiplin sebanyak 19 sudah membudayakan dan 15 siswa mulai berkembang. Aspek bertanggung jawab ada 11 siswa sudah membudayakan dan 23 mulai berkembang. Sedangkan pada aspek percaya diri ada 18 siswa sudah membudayakan dan 16 siswa mulai berkembang.

Hasil belajar ranah Psikomotorik siswa dengan menggunakan metode pembelajaran Talking Stick dikleas V SDN 01 Sepauk mengalami peningkatan. Pada siklus I siswa yang mendapat predikat A sebanyak 1 siswa dan meningkat pada siklus II sebanyak 26 siswa, 4 siswa mendapat predikat B pada siklus I dan jumlah siswa yang mendapat predikat B meningkat sebanyak 7 siswa pada siklus II, 20 siswa pada siklus I mendapat predikat $\mathrm{C}$ dan jumlah siswa yang mendapat predikat $\mathrm{C}$ pada siklus II berkurang menjadi 1 siswa, 9 siswa pada siklus I mendapat predikat D dan pada siklus II tidak ada siswa yang mendapatkan predikat $\mathrm{D}$.

Metode pembelajaran Talking Stick dapat memberikan motivasi kepada siswa dalam belajar. Apabila guru mengajar lagi dengan menggunakan metode pembelajaran yang sama yaitu metode pembelajaran Talking Stick, semua siswa menjawab akan bersemangat. Siswa memberikan kesan yang positif dengan hasil belajar yang mereka dapatkan.

\section{SIMPULAN}

Berdasarkan penelitian yang telah dilaksanakan mengenai penerapan metode pembelajaran Talking Stick untuk meningkatkan hasil belajar siswa padaa pembelajaran tematik di kelas V SDN 01 Sepuak tahun pelajaran 2019/2020, diperoleh kesimpulan sebagai berikut: 1) Penerapan metode pembelajaran Talking Stick untuk meningkatkan hasil belajar siswa padaa pembelajaran tematik di kelas V SDN 01 Sepuak tahun pelajaran 2019/2020 berlangsung dengan baik. Hasil observasi guru pada siklus I diperoleh diperoleh rata-rata 78\% dengan kriteria "BAIK". Sedangkan hasil observasi pada siklus II diperoleh rata-rata dengan hasil 96\% dengan kriteria "BAIK". Begitu pula pada hasil observasi siswa siklus I dengan rata-rata 78\% dengan kriteria BAIK meningkat pada siklus II menjadi 96\% dengan kriteria SANGAT BAIK; 2) Hasil belajar siswa kelas V SDN 01 Sepauk mengalami peningkatan dengan menggunakan metode pembelajaran Talking Stick pada pembelajaran tematik. Hal ini ditunjukan dengan peningkatan pada siklus I ranah kognitif dengan rata-rata 75 dengan ketuntasan klasikal sebesar 72\% (26 siswa) meningkat pada siklus II dengan rata-rata 92 dengan ketuntasan klasikal sebesar 94\% (23 siswa). Pada penilaian ranah afektif atau sikap, terjadi peningkatan sebanyak 21 siswa sudah membudayakan sikap jujur dan 13 siswa mulai berkembang. Pada aspek disiplin sebanyak 19 sudah membudayakan dan 15 siswa mulai berkembang. Aspek bertanggung jawab ada 11 siswa sudah membudayakan dan 23 mulai berkembang. Pada aspek percaya diri ada 18 siswa sudah membudayakan dan 16 siswa mulai berkembang. Sedangkan pada penilaian keterampilan atau 
Vol. 5, No. 1, April 2020

e-ISSN: 2540-7996

http://jurnal.stkippersada.ac.id/jurnal/index.php/KAN/index

psikomotorik terjadi peningkatan, ada 26 siswa mendapat nilai dengan predikat A, 7 siswa mendapat nilai dengan predikat $\mathrm{B}$, dan 1 siswa mendapat nilai dengan predikat C; 3) Respon yang diberikan siswa yang sangat baik terhadap penggunaan metode pembelajaran Talking Stick untuk meningkatkan hasil belajar siswa padaa pembelajaran tematik di kelas V SDN 01 Sepuak tahun pelajaran 2019/2020. Respon siswa terlihat pada hasil dari wawancara langsung dimana siswa senang dengan diterapkannya metode pembelajaran Talking Stick karena siswa bisa lebih mudah belajar dan lebih harus memperhatikan guru saat menjelaskan, siswa merasa bisa belajar sambil bermain, bisa membuat siswa merasa senang dan proses pembelajaran tidak monoton, selain itu siswa juga tidak merasa kesulitan saat menjawab pertanyaan.

\section{DAFTAR PUSTAKA}

Andriyani, M. Dkk. 2017. "Pengaruh Penggunaan Model Pembelajaran Talking Stick Terhadap Hasil Belajar Siswa Pada Pembelajaran Terpadu Kelas Iv Sd Negeri 1 Palapa”. Jurnal Skripsi Fakultas Keguruan Dan Ilmu Pendidikan Universitas Lampung Bandar Lampung.

Arikunto, S. 2013. Prosedur Penelitian. Jakarta: Rineka Cipta. Bumi Aksara.

Hasibuan, S.A. 2018. "Upaya Meningkatkan Hasil Belajar Siswa Dengan Menggunakan Model Pembelajaran Talking Stick Pada Mata Pelajaran Ipa Materi Gaya Di Kelas V Min Medan Maimun Kelurahan Timbang Deli Kecamatan Medan Amplas”. Skripsi. Medan: Universitas Islam Negeri Sumatera Utara.

Lahir, M. dan Zuldafrial. 2012. Penelitian Kualitatif. Suarakarta: Yuma Pressindo.

Mulyasa, E, H. 2013. Praktik penelitian Tindakan kelas. Bandung: Pt Remaja Rosdakarya.

Moleong, Lexy J. 2013. Metode Penelitian Kualitatif. Edisi Revisi. Bandung : PT. Remaja Rosdakarya. 


\section{Petunjuk Bagi (Calon) Penulis Jurnal KANSASI}

1. Artikel yang ditulis untuk Jurnal KANSASI adalah hasil telaah dan hasil penelitian dibidang pendidikan, bahasa, dan sastra Indonesia serta tidak pernah diterbitkan dimedia lain, baik cetak maupun elektronik.

2. Naskah diketik dengan huruf Times New Romans, ukuran 12, dengan spasi 1,5, menggunakan kertas A4, margin atas, kiri, kanan dan bawah $2.54 \mathrm{~cm}$, dengan maksimum 20 halaman, dan diserahkan secara online melalui laman (http://jurnal.stkippersada.ac.id/jurnal/index.php/KAN) pada bagian submission, dan terlebih dahulu penulis melakukan registrasi sebagai penulis (author). Pada saat diserahkan, file dalam format $p d f$.

3. Nama penulis artikel dicantumkan tanpa gelar akademik dan di tempatkan di bawah judul artikel. Nama penulis hendaknya dilengkapi dengan alamat lembaga tempat penelitian serta alamat korespondensi. Bila naskah ditulis oleh tim, maka penyunting hanya berhubungan dengan penulis utama.

4. Artikel ditulis dalam bahasa Indonesia dengan format esai, disertakan judul masingmasing bagian artikel. Judul artikel dicetak dengan huruf kapital dengan posisi tengah atas dengan ukuran huruf 14 serta ditebalkan.

5. Sistematika artikel hasil telaah adalah: judul, nama penulis (tanpa gelar), identitas lembaga, alamat e-mail, abstrak (maksimum 250 kata), kata kunci, pendahuluan; pembahasan, simpulan, dan daftar pustaka.

6. Sistematika artikel hasil penelitian adalah: judul, nama penulis (tanpa gelar), abstrak (maksimum 250 kata), pendahuluan, metode penelitian, pembahasan, simpulan, dan daftar pustaka.

7. Sumber rujukan minmal terbitan sepuluh tahun terkahir. Rujukan yang diutamakan adalah sumber-sumber primer berupa laporan penelitian, atau artikel penelitian terbitan jurnal ilmiah.

8. Perujukan, pengutipan, tabel, dan gambar menggunakan ketentuan yang ada pada template penulisan artikel ilmiah pada Jurnal KANSASI.

9. Naskah diketik sesuai dengan tata bahasa baku bahasa Indonesia.

10. Setiap naskah ditelaah oleh penyunting ahli (reviewer) yang ditunjuk oleh penyunting sesuai dengan bidang kepakaran. Penulis artikel diberi kesempatan untuk merivisi naskah berdasrkan rekomendasi dari penyunting. Pemuatan atau penolakan naskah akan diberitahukan secara online melalui e-mail.

11. Penyuntingan naskah pra-terbit dikerjakan oleh penyunting (editor). Naskah pra-terbit dapat batal diterbitkan apabila diketahui bermasalah.

12. Segala sesuatu yang menyangkut perizinan atau penggunaan software computer untuk pembuatan naskah atau hal lain yang terkait dengan pelanggaran hak cipta yang dilakukan oleh penulis, serta konsekuensi hukum yang mungkin timbul karenanya, sepenuhnya menjadi tanggungjawab penulis. 